\title{
Fetomaternal outcome in women with hemolysis, elevated liver enzymes and low platelet count syndrome: a retrospective study
}

\section{B. Divya ${ }^{1}$, Nishi Roshini Kondakasseril ${ }^{1 *}$, Mekkattukunnel Andrews Andrews}

\author{
${ }^{1}$ Department of Obstetrics and Gynecology, Government Medical College, Thrissur, Kerala, India \\ ${ }^{2}$ Department of Medicine, Government Medical College, Thrissur, Kerala, India
}

Received: 10 July 2020

Accepted: 05 August 2020

\section{*Correspondence:}

Dr. Nishi Roshini Kondakasseril,

E-mail: nishiroshini@gmail.com

Copyright: (c) the author(s), publisher and licensee Medip Academy. This is an open-access article distributed under the terms of the Creative Commons Attribution Non-Commercial License, which permits unrestricted non-commercial use, distribution, and reproduction in any medium, provided the original work is properly cited.

\section{ABSTRACT}

Background: HELLP (hemolysis, elevated liver enzymes and low platelet count) syndrome which is a variant form of severe preeclampsia is an important cause of maternal and fetal mortality and morbidity. The importance lies in the early diagnosis and timely intervention for better fetal and maternal outcome. The objective of this study was to assess the maternal and fetal outcome in pregnancies complicated with HELLP syndrome.

Methods: This is a retrospective study analyzing fetomaternal outcome in 63 women diagnosed with HELLP syndrome in the department of obstetrics and gynecology, Government Medical College, Thrissur from $1^{\text {st }}$ January 2014 to $31^{\text {st }}$ December 2016. Details were collected from data records library.

Results: Among 7,566 deliveries, 63 women (0.83\%) had HELLP syndrome. Mean age was 29.5 years. $47.6 \%$ $(\mathrm{n}=30)$ women developed HELLP syndrome at gestational age less than 34 weeks. Maternal complications were abruption (27.78\%), acute kidney injury (16.67\%), DIC (16.67\%), sepsis $(11.11 \%)$ and postpartum hemorrhage $(11.11 \%)$. In this study, HELLP syndrome lead to one maternal death (1.58\%). The perinatal mortality was $25.75 \%$.

Conclusions: HELLP syndrome is an alarming complication, which brings high maternal and perinatal morbidity and mortality.

Keywords: Hemolysis elevated liver enzymes and low platelet count, Maternal morbidity, Maternal mortality, Perinatal morbidity perinatal mortality, Preeclampsia,

\section{INTRODUCTION}

The HELLP syndrome is a serious complication in pregnancy characterized by a triad of hemolysis, elevated liver enzymes, and low platelet count occurring in 0.5 to $0.9 \%$ of all pregnancies and in $10-20 \%$ of cases with severe preeclampsia. ${ }^{1}$ The syndrome was originally identified by Dr Louis Weinstein in 1982. The condition regarded as a variant or a complication of severe preeclampsia, and the diagnosis of the complete form requires the presence of all the major components, while partial or incomplete HELLP syndrome consists of only 1 or 2 elements of the triad. ${ }^{3}$ There are 2 classification systems - Mississippi classification and Tennessee Classification.
HELLP is a complication due to hepatic ischemia, giving rise to periportal hemorrhage and necrosis along with microangiopathic haemolytic anemia and thrombocytopenia. HELLP syndrome is rapid onset and is typically seen in patients with severe pre-eclampsia, although it can occur in the absence of pre-eclampsia in $10 \%$ of the cases. Excessive weight gain and generalized edema precede the syndrome in more than $50 \%$ of the cases. The incidence of subcapsular liver hematoma was 1.6 percent. Other complications included eclampsia - 6 percent, placental abruption - 10 percent, acute kidney injury - 5 percent, and pulmonary edema - 10 percent. $^{2}$ Other serious complications included stroke, coagulopathy, acute respiratory distress syndrome, and sepsis. The risk of recurrence of HELLP syndrome is 
$24 \%$ after the index pregnancy. In the study by Chawla et al found that $0.45 \%$ of the patients admitted for delivery developed HELLP syndrome and majority of the patients developed the condition in 30-36 weeks period of gestation, while five patients developed it in the postpartum period. ${ }^{3}$

This study was undertaken with the objective to assess the prevalence, severity and complications of HELLP syndrome and to evaluate the maternal and fetal outcome in pregnancies complicated with HELLP syndrome.

\section{METHODS}

This is a retrospective study carried out in the department of obstetrics and gynecology, Government Medical College, Thrissur, Kerala, India, a tertiary care from $1^{\text {st }}$ January 2014 to $31^{\text {st }}$ December 2016 (3 years).

\section{Inclusion criteria}

The inclusion criteria were those who were diagnosed to have partial or complete HELLP syndrome.

\section{Exclusion criteria}

The exclusion criteria were women diagnosed with AFLP, chronic liver diseases, viral hepatitis, immune thrombocytopenia and renal diseases.

The maternal parameters assessed were age, parity, gestational age, booking status, blood pressure, liver function tests, renal function tests, platelet count, presence of proteinuria, mode of delivery, need of blood transfusion and maternal complications like abruption, eclampsia, renal failure, sepsis and maternal mortality. Baby details included birth weight, Apgar, live or dead, presentation, prematurity and perinatal mortality. The gestational age of the pregnancy was determined from the last menstrual period or early sonography. The diagnosis and classification of HELLP syndrome were made using the criteria - complete or partial HELLP depending on the components involved and Mississippi classification - i.e., abnormal peripheral blood smear with evidence of haemolysis, raised lactic dehydrogenase (LDH) (>600 U/L), elevated liver enzymes [increased plasma aspartate amino transferase (AST) (70 U/L), and low platelets (platelet count less than 1.5 lakh). Other associated complications in the mother and the perinatal outcome in terms of the intrauterine fetal demise, preterm delivery and Apgar were also noted.

The clinical data included blood pressure, signs of impending eclampsia (headache, blurring of vision, epigastric pain), while the laboratory investigations recorded were serial measurement of complete blood cell count, liver function tests (S bilirubin, ALT, AST), and renal function tests (B urea, $S$ creatinine). The study started after getting ethical clearance. The descriptive data presented as number and percentages with mean using excel sheet.

\section{RESULTS}

During the study period, there were a total of 7,566 deliveries. Among them, 1,139 women had hypertension complicating pregnancy. A total of 63 cases of HELLP syndrome were diagnosed. Of total deliveries, $608(8 \%)$ had preeclampsia. $49(77.78 \%)$ women with preeclampsia developed HELLP syndrome. The mean age was 29.5 years. 26 women $(41.2 \%)$ were in the age group of $26-30$ years.

Table 1: Gestational age.

\begin{tabular}{|lll|}
\hline Gestational age (weeks) & Number & Percentage \\
\hline$<\mathbf{2 8}$ weeks & 1 & 1.59 \\
\hline $\mathbf{2 8 - 3 4}$ weeks & 29 & 46.03 \\
\hline $\mathbf{3 4 - 3 7}$ weeks & 32 & 50.79 \\
\hline$>$ 37 weeks & 1 & 1.59 \\
\hline
\end{tabular}

A total $30(47.6 \%)$ patients were admitted with HELLP syndrome at less than 34 weeks of gestation. One woman with gestational age less than 28 weeks (Table 1). HELLP syndrome was seen in $31(49.2 \%)$ primigravida and $32(50.7 \%)$ multigravida, almost same. There were three cases of twin pregnancy. All were booked cases, but 17 (26.98\%) women had irregular ANC.

Table 2: Platelet count.

\begin{tabular}{|lll|}
\hline Platelet (lakh) & Number & Percentage \\
\hline $\mathbf{0 0 . 5}$ & 2 & 3.18 \\
\hline $\mathbf{0 . 5}-1$ & 10 & 15.87 \\
\hline $\mathbf{1 - 1 . 5}$ & 15 & 23.8 \\
\hline $\mathbf{> 1 . 5}$ & 36 & 57.15 \\
\hline
\end{tabular}

A total $14(22.2 \%)$ cases were having normal blood pressure. Majority of them, 49 patients (77.78\%) had severe pre-eclampsia. Maximum blood pressure recorded was $210 / 110 \mathrm{mmHg}$.

Table 3: Bilirubin value.

\begin{tabular}{|lll|}
\hline Bilirubin $(\mathbf{m g} \%)$ & Number & Percentage \\
\hline $\mathbf{1 1 . 2}$ & 28 & 44.44 \\
\hline $\mathbf{1 . 2}-\mathbf{4}$ & 33 & 52.38 \\
\hline $\mathbf{> 4}$ & 2 & 3.18 \\
\hline
\end{tabular}

Table 4: Birth weight.

\begin{tabular}{|lll|}
\hline Birth weight $\mathbf{( k g )}$ & Number & Percentage \\
\hline $\mathbf{1}$ & 13 & 19.7 \\
\hline $\mathbf{1 - 1 . 5}$ & 17 & 25.76 \\
\hline $\mathbf{1 . 5}-\mathbf{2}$ & 18 & 27.27 \\
\hline $\mathbf{2 - 2 . 5}$ & 11 & 16.67 \\
\hline $\mathbf{2 . 5}$ & 7 & 10.6 \\
\hline
\end{tabular}


Two patients developed severe PPH. Two patients developed antepartum eclampsia. One case had ascites. Investigations of these patients showed that the platelet count was less than 50,000 in two cases, 50,000-100,000 in ten cases, and the rest had a platelet count more than 100,000 (Table 2). Transaminases were also raised in all the cases. Mean AST level of 185.6 IU/L and mean ALT of 143.7 IU/L. 35 cases had bilirubin more than 1.2 (Table 3). ${ }^{13}$ Cases showed evidence of hemolysis in peripheral smear. Of total, 50 patients $(79.3 \%)$ were having partial HELLP and $13(20.7 \%)$ with complete HELLP (Figure 1).

Of these 63 patients, $11(17.46 \%)$ women required blood transfusion - including packed red cells, fresh frozen plasma, platelets, $6(9.5 \%)$ women required 2 pint packed red cells, 3 required 3 pint packed red cells, 2 pint fresh frozen plasma and 2 platelets, 1 (1.58\%) required 1pint packed red cell and 1 required 5 pint packed red cell, 4 fresh frozen plasma and 2 platelets. 33 patients $(52.3 \%)$ underwent caesarean section and the common indications were previous CS and fetal distress.

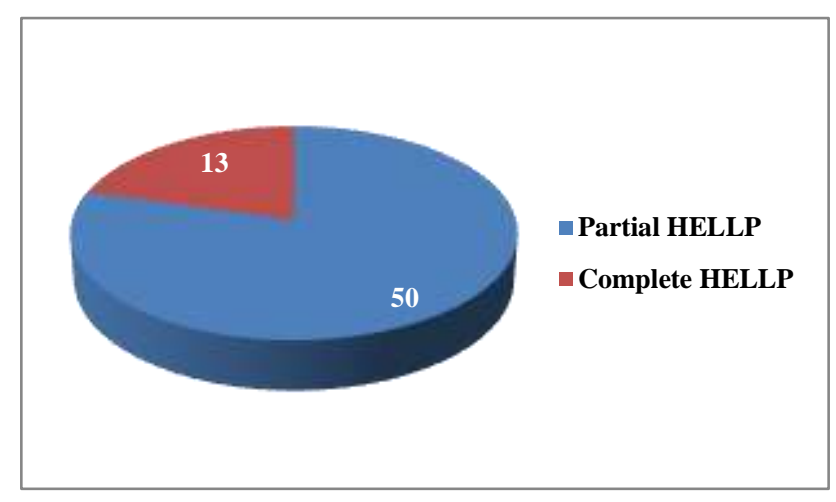

Figure 1: Complete and partial HELLP.

Table 5: Fetal complications.

\begin{tabular}{|lll|}
\hline Neonatal outcome & Number & Percentage \\
\hline Intrauterine fetal demise & 12 & 48 \\
\hline Low Apgar $(<7)$ & 8 & 32 \\
\hline Neonatal death & 5 & 20 \\
\hline Total & 25 & 100 \\
\hline
\end{tabular}

Table 6: Maternal complications.

\begin{tabular}{|lll|}
\hline Maternal complications & Number & Percentage \\
\hline Abruption & 5 & 27.78 \\
\hline Acute renal failure & 3 & 16.67 \\
\hline DIC & 3 & 16.67 \\
\hline Sepsis & 2 & 11.11 \\
\hline Postpartum hemorrhage & 2 & 11.11 \\
\hline Eclampsia & 2 & 11.11 \\
\hline Death & 1 & 5.55 \\
\hline Total & 18 & 100 \\
\hline
\end{tabular}

There were $12(18.2 \%)$ cases of intrauterine fetal demise, which was confirmed with sonography. Eight babies born with low Apgar (less than 7) and five cases of neonatal deaths mainly due to prematurity and very low birth weight. $89 \%$ neonates were having birth weight less than $2.5 \mathrm{~kg}$ (Table 4). Overall perinatal mortality was $25.76 \%$ (Table 5). There were $5(27.78 \%)$ cases of abruption, of which one was grade $3 \mathrm{~A}$ abruption, 3 (16.67\%) women with acute renal failures - two underwent dialysis and one patient conservatively managed. $3(16.67 \%)$ women had DIC, $2(11.11 \%)$ women had sepsis, $2(11.11 \%)$ cases of postpartum hemorrhage and $2(11.11 \%)$ women had antepartum eclampsia (Table 6). One maternal death among 63 women, death was due to DIC and sepsis, she had complete HELLP.

\section{DISCUSSION}

HELLP syndrome is a life-threatening complication. The incidence of HELLP syndrome in this retrospective study is $0.84 \%$ (63 cases) as compared to $0.45 \%$ (24) in the study by Chawla et al and $0.2 \%$ (71) in the study by Campos et al., ${ }^{3,4}$ This is based on the total number of deliveries. In this study, $8 \%$ (608) had preeclampsia and $77.78 \%$ (49) of women with preeclampsia developed HELLP syndrome, but in the study by Campos et al, HELLP syndrome diagnosed only in $28 \%$ of severe preeclampsia and similarly in the study by Pampus et al only $13.18 \%$ of severe preeclampsia developed HELLP yndrome. ${ }^{4,11}$

In this study, mean age was 29.5 years and majority, $41.2 \%$ (26 women) were in the age group 26-30 years as compared to the study by Chawlal et al mean age was 24.25 years and in the study by Campos et al the mean age was 31 years and $33.3 \%$ with age more than 35 years. ${ }^{3,4}$ In this study, $47.6 \%$ (30) patients were admitted with HELLP syndrome at less than 34 weeks of gestation and $49.2 \%$ (31) primigravidae and $50.7 \%$ (32) multigravida. All were booked cases, but $26.98 \%$ (17) women had irregular ANC. There were $68.3 \%$ of nulliparous in the study by Campos et al. ${ }^{4} 42 \%$ with gestational age less than 32 weeks in the study by Gasem et al and $73.3 \%$ between $32-38$ weeks in the study by Kota et al. ${ }^{6,9}$

In this study, all (63) were antenatal cases and among them, $79.3 \%$ (50) had partial HELLP and $20.7 \%$ (13) had complete HELLP as compared to $64 \%$ were antenatal cases in the study by Fitzpatrick et al and $70 \%$ antenatal cases in the study by Sibai et al. ${ }^{5,8}$ In the study of Haddad et al $22 \%$ (41) required blood transfusion as compared to $17.46 \%$ (11) women in this study. ${ }^{10} 52.3 \%$ (33) underwent caesarean section in this study which was lower than $91 \%$ CS in the study by Fitzpatrick et al.8 In the study of Fitzpatrick et al 50\% (65) had platelet count of less than 50,000 as compared to only $3.18 \%$ (2) had platelet count less than $50,000 .^{8}$ 
In this study, maternal complications were abruption $27.78 \%$ (5), acute renal failures $16.67 \%$ (3), DIC $16.67 \%$ (3), sepsis $11.11 \%$ (2), postpartum hemorrhage $11.11 \%$ (2) and antepartum eclampsia $11.11 \%$ (2) and one maternal death due to DIC and sepsis. There were 54 maternal deaths in the study by Isler et al, $6.6 \%$ maternal mortality in the study by Pampus et al and no maternal deaths in the studies by Campos et al and Gaseem et al. ${ }^{4,7,9,11}$ There were $54 \%$ abruption, $29 \%$ eclampsia, $8 \%$ DIC and $12.5 \%$ renal failure in the study by Chawla et al. $^{3}$ In this study, there were $12(48 \%)$ cases of intrauterine fetal demise, eight babies (32\%) born with low Apgar (less than 7) and five cases of neonatal deaths with $25.76 \%$ perinatal mortality when compared to $46.6 \%$ in the study by Kota et al. ${ }^{6}$

\section{CONCLUSION}

HELLP syndrome is an alarming complication, which brings high maternal and perinatal morbidity and mortality. The termination of pregnancy is the definitive treatment for HELLP.

Syndrome and it should be treated only in a tertiary care center, as it needs a multidisciplinary team approach work by the obstetrician, paediatrician, physician, transfusion medicine specialist, anaesthesiologist etc.

\section{ACKNOWLEDGMENTS}

Authors would like to thank all teachers and guide.

Funding: No funding sources

Conflict of interest: None declared

Ethical approval: The study was approved by the Institutional Ethics Committee

\section{REFERENCES}

1. Cunningham F, Leveno $\mathrm{K}$, Bloom S, Spong CY, Dashe J. Williams obstetrics $25^{\text {th }}$ ed. Mcgraw-hill; 2018:722-723.

2. American College of Obstetrics and Gynecologists. Taskforce on hypertension in pregnancy. hypertension in pregnancy/developed by the taskforce on hypertension in pregnancy. ACOG; 2013:34

3. Chawla S, Marwaha A, Agarwal R. HELLP or help: a real challenge. $J$ Obstet Gynecol India. 2015;65(3):172-5.
4. Campos AC. HELLP syndrome, a severe form of preeclampsia: a comparative study of clinical and laboratorial parameters. Am J Experiment Clin Res. 2016;3(3):170-4.

5. Sibai BM, Ramadan MK, Usta I, Salama M, Mercer BM, Friedman SA. Maternal morbidity and mortality in 442 pregnancies with hemolysis, elevated liver enzymes, and low platelets (HELLP syndrome). Am J Obstet Gynecol. 1993;169(4):1000-6.

6. Kota LN, Garikapati K, Kodey PD, KB G. Study on HELLP syndrome-maternal and perinatal outcome. Int J Reprod Contracept Obstet Gynecol. 2017;6(2):715.

7. Isler CM, Rinehart BK, Terrone DA, Martin RW, Magann EF, Martin JN. Maternal mortality associated with HELLP (hemolysis, elevated liver enzymes, and low platelets) syndrome. Am J Obstet Gynecol. 1999;181(4):924-8.

8. Fitzpatrick KE, Hinshaw K, Kurinczuk JJ, Knight M. Risk factors, management, and outcomes of hemolysis, elevated liver enzymes, and low platelets syndrome and elevated liver enzymes, low platelets syndrome. Obstet Gynecol. 2014;123(3):618-27.

9. Gasem T, Al Jama FE, Burshaid S, Rahman J, Al Suleiman SA, Rahman MS. Maternal and fetal outcome of pregnancy complicated by HELLP syndrome. J Maternal-Fetal Neonat Med. 2009;22(12):1140-3.

10. Haddad B, Barton JR, Livingston JC, Chahine R, Sibai BM. Risk factors for adverse maternal outcomes among women with HELLP (hemolysis, elevated liver enzymes, and low platelet count) syndrome. Am J Obstet Gynecol. 2000;183(2):444-8.

11. Van Pampus MG, Wolf H, Westenberg SM, van der Post JA, Bonsel GJ, Treffers PE. Maternal and perinatal outcome after expectant management of the HELLP syndrome compared with pre-eclampsia without HELLP syndrome. Eu J Obstet Gynecol Reprod Biol. 1998;76(1):31-6.

Cite this article as: Divya MB, Kondakasseril NR, Andrews MA. Fetomaternal outcome in women with hemolysis, elevated liver enzymes and low platelet count syndrome: a retrospective study. Int J Reprod Contracept Obstet Gynecol 2020;9:3798-801. 